\title{
Analysis of Tree Stratum Vegetation in Sand Dune Core Zone in Parangtritis Village Kretek Sub-District Bantul Regency Yogyakarta As Learning Sources on Biodiversity for Grade X Senior High School
}

\author{
Trikinasih Handayani ${ }^{1, *}$, Nur Hidayat ${ }^{2}$ \\ \{trikinsihhandayani@gmail.com ${ }^{1}$, dayat0222@gmail.com ${ }^{2}$ \} \\ Biology Education Universitas Ahmad Dahlan, Jl. Jend. A.Yani, Tamanan, Banguntapan, Bantul, \\ Yogyakarta, Indonesia ${ }^{1,2}$ \\ *Corresponding Author
}

\begin{abstract}
The research aims to know the species of tree stratum in the Sand Dune Core Zones of Parangtritis and their significant roles according to the Importance Value Index (IV). Besides, it is to examine the influence of abiotic environment (soil temperature, air temperature, light intensity, humidity, and soil $\mathrm{pH}$ ) on the tree diversity in the sand dunes as well as the potential of the research results to be the learning materials for biology subject, particularly biodiversity, for Senior High School.

The samples were taken using the Point Centered Quarter (PCQ) method in the Sand Dunes Core Zones that is spread through $141 \mathrm{Ha}$. The area was divided into three, $14 \mathrm{Ha}$ for each. The vegetation parameter covers density, dominance, frequency, Importance Value Index, and Diversity Index. The influence of the abiotic environment was revealed using linear regression analysis. The results were then analyzed for the potentials to be used as the learning materials in biology subjects for grade x Senior High School.

The study found six species of tree vegetation. The tree having the highest Importance Value Index is Acasia auricliformis (124.17\%), while the lowest is Psidium guajava (3.26\%). The measured abiotic environments do not influence the index of vegetation diversity in the sand dunes. The results are potential to use as learning materials for grade X senior high school. The aspects include object availability and the issues in question; suitability with the learning objectives; aims and purposes; information clarity; exploration guidelines; and the outcome
\end{abstract}

Keywords: Tree Stratum Vegetation, Sand Dunes Core Zone, Learning Source

\section{Introduction}

The dune is formed by wind and it moves all the time as the results of wind activities. Dunes can be identified by their basic form. In Parangtritis, we can find three of their species: parabolic, barchan, and linear. Barchan is only found in Indonesia. Indeed, it only exists in Southeast Asia. It is a unique and rare ecosystem [1].

Sand dunes are controlled by environmental factors, such as soil temperature, air temperature, light intensity, humidity, and soil ph. Trees play important roles in the area, in that it determines the patterns of a particular ecosystem. 
According to Soerianegara and Indrawan [2] analyzing vegetation is one of the ways to study the structure and composition of the plant in a particular area by describing them. The research on tree stratum in Sand Dunes Core Zone helps students to learn that nature with all the phenomena provides them with abundant information about biodiversity. [3] stated that one way to make students learn is to bring them to the field, allowing them to increase their knowledge and insight, particularly in biology subject for grade X senior high school.

\section{Methods}

The study belongs to explorative research. It was carried out in the Sand Dunes Core Zones of Parangtritis village, with the western boundary of Pelangi Beach, East of Parangtritis Beach, and North of Southern Ring Road.

The study was conducted during the dry season, from June to July. It employed several types of equipment, such as the Map of the Sand Dunes Core Zones, Roller-type meter counter, pole, GPS, camera, stationery, thermometer, hygrometer, Lux-meter, and Soil-tester. Meanwhile, the materials of the study included the tree stratum in the Sand Dune Core Zones of Parangtritis village, Kretek Sub-district, Bantul Regency, Yogyakarta.

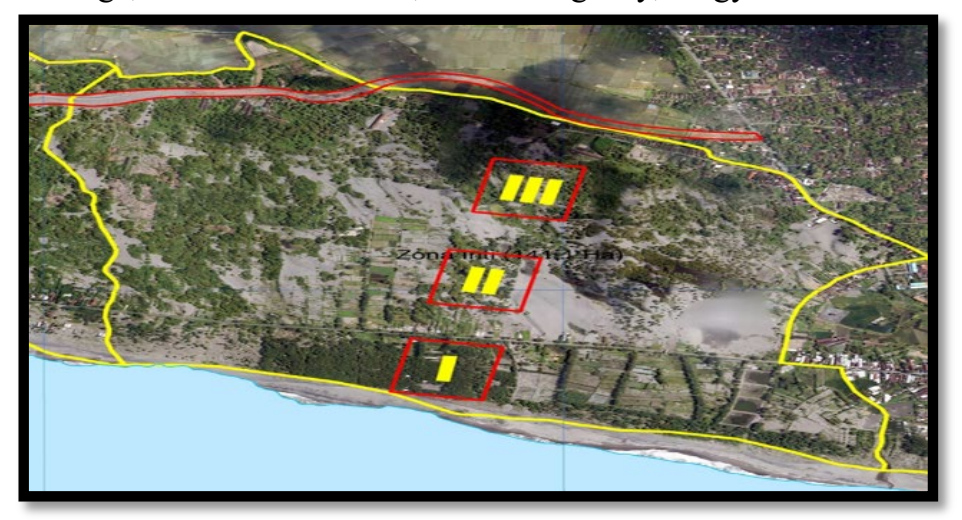

Figure 1. Sand Dunes Core Zones area in Parangtritis village, Kretek sub-district, Bantul Regency, Yogyakarta

\subsection{Procedures}

1. The preliminary observation was conducted to know the area of the Sand Dunes Core Zones

2. Of all the areas, only $10 \%$ was taken as the study area.

3. The selected areas were divided into three. Study Area I was near the seashore, Area II in the middle, and Area III in the northern part of the sand dunes. Each of them is 50.000 $\mathrm{m}^{2}$.

4. Each study area was divided into five stands with the size $50 \mathrm{~m} \times 200 \mathrm{~m}$.

5. The main transect line was drawn along $200 \mathrm{~m}$ with the sub-transect line in every $20 \mathrm{~m}$. Therefore, there will be 10 sampling spots. Each spot is in the form of four quadrants. 
6. Each quadrant was measured from the intersection of the main transect line and the subtransect line of the closest tree that was found. It continued with the next closest tree found.

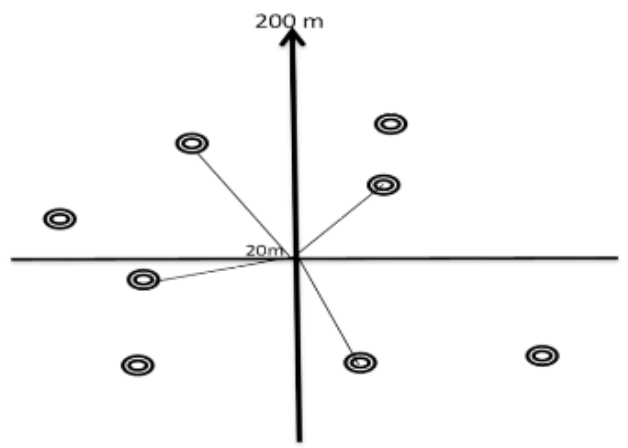

Figure 2. The intersection of the main transect line and the sub-transect line with the closest tree.

7. The tree trunk diameter was measured at breast height of an adult (if the tree is small, the basal measurement is based on the soil surface).

8. The observation results were added to the table that includes all the name of the measured plants

9. Each stand was measured based on the vegetation parameter that includes density, dominance, frequency, Importance Value Index (IV), and Diversity Index (ID).

10. Further, the abiotic environment conditions found in each stand were examined the effect of diversity index.

11. The result of this reseacrh will be review as learning resource for biodiversity at grade $\mathrm{X}$ senior high school refer to Djohar [4]

\section{Results}

A. The Importance Value Index (IV) or the tree stratum of all the studied area.

The research conducted in the laboratory of plant taxonomy of UGM found six species of tree stratum in all the studied area. They are Casuarina litorea(beach she-oak), Glirisedia sepium(Glirisedia), Acacia auriculiformis(Acacia), Borassus flabellifer(palmyra palm), Psidium guajava(yellow guava) dan Acacuba accidentalis (Cashew fruit). The IV scores of all the areas (I, II, and III) are presented in Figure 3. 


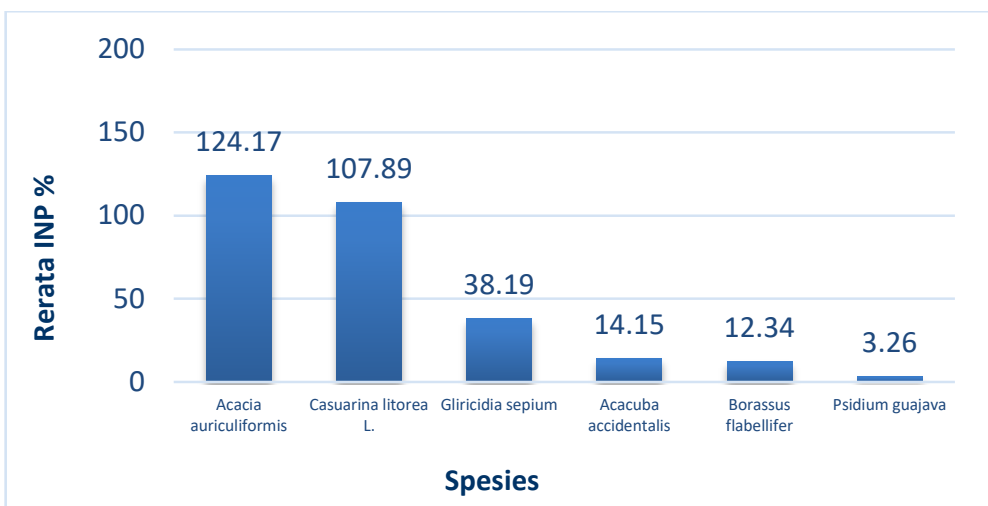

Figure 3. Chart of Importance Value Index (IV) of Tree Stratum in all the Studied Area

Figure 3 presents the IV score of the six species of vegetation in the Sand Dunes Core Zones. The highest was Acacia auriculiformis(124.17\%), followed by Casuarina litorea L (107.89\%), Glirisedia sepium (38.19\%), Acacuba accidentalis L (14.15\%). Meanwhile, the low scores were achieved by Borassus flabellifer (12.34\%), followed by Psidium guajava $(3.26 \%)$.

B. Diversity Index (ID) of the vegetation of the tree stratum

The measurement of the Diversity Index to the tree stratum in the Sand Dunes was shown in Figure 4.

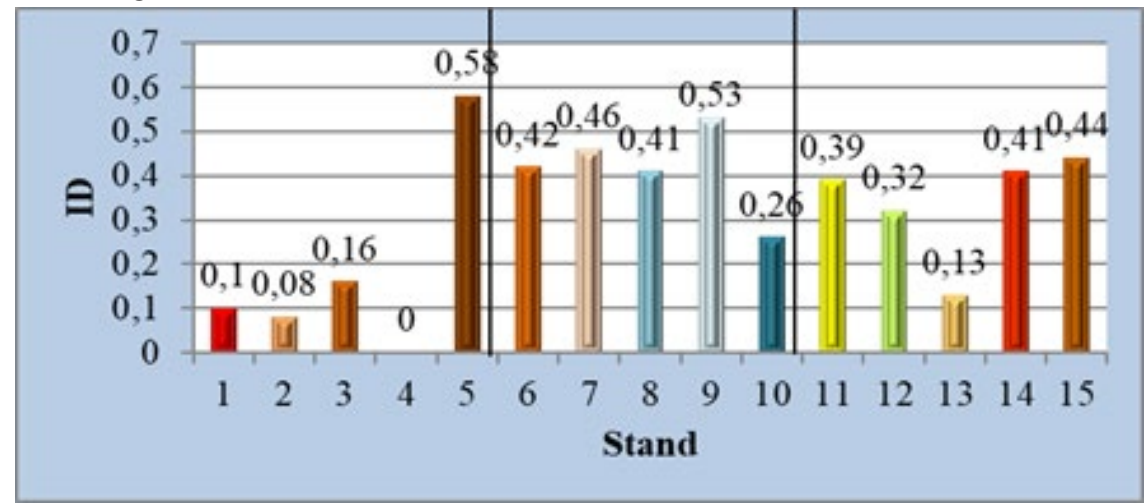

Figure 4. Chart for Diversity Index of the Vegetation of Tree Stratum in all Studied Area.

\section{Regression Analysis}

Table 1 shows the influence of the measured abiotic environment on the diversity index of the tree stratum in Parangtritis village.

\begin{tabular}{|c|c|c|c|c|c|}
\hline Measured Environment & & $\mathrm{R}$ & & & \\
\hline Condition & $\mathrm{R}$ & Square & Sig & Equation & Notes \\
\hline Soil Temperature & 0,179 & 0,032 & 0,524 & $\mathrm{Y}=-0,006,0,010 \mathrm{X}$ & No influence \\
\hline
\end{tabular}




\begin{tabular}{llllll}
\hline Air Temperature & 0,165 & 0.027 & 0,556 & $\mathrm{Y}=0,729,-0,013 \mathrm{X}$ & No influence \\
\hline Soil $\mathrm{pH}$ & 0,033 & 0,001 & 0,907 & $\mathrm{Y}=-0,219,0,078 \mathrm{X}$ & No influence \\
\hline Air Humidity & 0,248 & 0,062 & 0,373 & $\mathrm{Y}=0,797,0,007 \mathrm{X}$ & No influence \\
\hline Light Intensity & 0,455 & 0,207 & 0,088 & $\mathrm{Y}=-0,275,0,001 \mathrm{X}$ & No influence \\
\hline Notes: & & & & \\
H0 rejected (sig<0.05) & $=$ Influential & & & \\
H0 accepted (sig $>0.05)$ & $=$ No Influence
\end{tabular}

The measured abiotic environments did not give a significant influence on vegetation diversity. It is evident in the significance rate, which was above 0.05 .

\section{Discussion}

A. Importance Value Index (IV)

Importance Value Index (IV) is the index to describe the significance of particular vegetation in the ecosystem. If the IV is high, it influences the stability of the relevant ecosystem[2]. Of all the six studied tree strata, the highest score was reached by Acacia auriculiformis (124.17\%), while the lowest was Psidium guajava (yellow guava) $(3.26 \%)$.

The IVscore of Acacia auriculiformis in all the studied area shows that the species dominates the area, particularly in utilizing the resources and in adapting to the surrounding environment [5]. If the IV score of particular vegetation is high, it will influence the stability of the ecosystem [2]. The results show the score of measured abiotic environment. The soil $\mathrm{pH}$ ranged from $6.78-6.84$, soil temperature $32.0^{\circ} \mathrm{C}$, air temperature $31.67^{\circ} \mathrm{C}$, air humidity $64.9 \%$ and light intensity 684.53lux.

The scores prove that the soil is ideal for the growth of Acacia auliculiformis in the Sand Dunes Core Zones in Parangtritis village. It is in line with the result [6], that the suitable soil $\mathrm{pH}$ is 6.64.that the suitable soil $\mathrm{pH}$ is 6.64. Similarly, [7] stated that the plant grows at the soil temperature of $26.16^{\circ} \mathrm{C}$, air temperature $27.06^{\circ} \mathrm{C}$, air humidity $84.06 \%$, and light intensity 2832.99 Lux.

Psidium guajava reached the lowest IV, which was 48.94. A species with low score means it is less adaptive to use the nutrients or to the climate, such as light, temperature, rainfall, and wind[5]. The scores find that the soil temperature ranged from $31^{\circ} \mathrm{C}-34.6^{\circ} \mathrm{C}$, air temperature $31^{\circ} \mathrm{C} 0-32.2^{\circ} \mathrm{C}$, light intensity $569.2-664.6$ lux, air humidity $63.650-65.6 \%$, and soil $\mathrm{pH}$ 6.78-6.84. These scores prove that the condition is not suitable for the habitat for Psidium guajava. According to [8], the suitable score for the maximum growth is $22^{\circ} \mathrm{C}-28^{\circ} \mathrm{C}$ for the air temperature and $70 \%-90 \%$ for the humidity. stated that the light intensity for vegetation should be 3283.7 lux.

\section{B. Diversity Index of Tree Vegetation in the Sand Dunes Core Zones}

The Mean score for the Diversity index of the tree vegetation in the area I was 0.18 , area II 0.42 , and area III 0.34 . In general, the score was in a low category. In relation to Shannon-Wienner[2], if $\mathrm{H}^{\prime}$ value $<1$, diversity of particular transect is low. The Diversity Index shows that the vegetation species are few and uneven. [9] suggested that a community is said to be in the low category if the structure consists only of a few dominating species. 
C. The Influence of Species Diversity of Tree Stratum Vegetation on the measured abiotic environment conditions

The measured abiotic environment (soil temperature, air temperature, air humidity, light intensity, and soil $\mathrm{pH}$ ) did not influence the vegetation diversity in the Sand Dunes Core Zones. It is evident in the significance score, which was above 0.05 .

\section{The Research Results as Biology Learning Source}

The findings are potential to be used as learning materials for grade $\mathrm{X}$ students of senior high school, particularly the basic competnce in Indonesian National curriculumn for Senior High School Level no. 3.2. (KD 3.2.) It is about describing gene diversity, species, and ecosystems through observation. The analysis follows the criteria proposed by Djohar[4]they are: 1) Those are the potentials of the object availability and the issues; the possible topic or the research object in this project include the vegetation species of tree stratum, which focuses on the rarity of good examples of contextualteaching-learning process for biodiversity materials at tenth grade senior high school level. 2) The relevance of the researchresult with the national learning objective of Biology subject at Senior High School level as seen in National Curriculum 2013 especially K.D. 3.2., which stipulates the specimens of vegetation tree stratum, which plays an important role ranging from the most to the least importance at sand dunes inParangtritis. The students are able to explain the concept of diversity. 3) the aim and purpose of the materials. The object of the research is the biodiversity whereas the material should meet the learning objectives of grade tenth students of Senior High School. 4) information clarity, a product and concept are obtained from the research. The research found out 6 species of vegetation tree stratum in sand dunes Parangtritis. The vegetation tree stratum having the most important value index is Acacia auriculiformis while the least important value index is Psidium guajava. 5) clarity of the exploration guidelines. It is understood that this research is based on the clear working procedure or clear exploration guideline. The working procedure starts from determining the location of research, finding the research object, research procedure, research tools and materials, data analysis, and drawing conclusions. 6) the clarity of the learning outcomes. That is the achievement of learning outcomes, which are expected to improve the students achievement in three domains i.e. cognitive, affective and psychomotor domains. The use of environment as learning resource is expected meaningful and interesting for the students. This is because the students are able to interact directly with the real environment. This thing is in accordance with [10]statement, which say that the use of environment in teachinglearning process can attract the students' interest. Furthermore, [11] say that the teachinglearning process, which involve the students in real environment as learning resource makes it possible for the students to study the material easily. Based on the result of the analysis of the learning resource, it can be concluded that sand dune core zone in Parangtritis is a potential learning resource for the learning material of biodiversity for the tenth grade students of Senior High School.

\section{Conclusion}

From the discussion, it can be concluded that there are six species of tree stratum in the Sand Dunes Core Zones in Parangtritis. Those are Casuarina litorea (beach she-oak), 
Glirisedia sepium (glirisedia), Acacia auriculiformis (acacia), Borassus flabellifer (palmyra palm), Psidium guajava (yellow guava) and Acacuba accidentalis $L$ (cashew fruit). The specieswith the highest Importance Value Index isAcacia auriculiformis (124.17\%), while the lowest oneisPsidium guajava (3.26\%). The result is they are potential to be used as the learning materials of biology for grade X students of senior high school, particularly for the material of biodiversity.

\section{References}

[1] Sutikno, Suhardi, H. . Nurjanto, and M. . Widodo, "Casuarina equisetifolia planting or rehabilitation of coastal sand dunes area," Procedings 11th Int. Work. Bio-Refor., pp. 143-150, 2002.

[2] F. Fachrul, Melati, Metode sampling bioekologis. Jakarta: Bumi Aksara, 2012.

[3] E. Mulyasa, menjadi guru profesional: menciptakan pembelajaran kreatif dan menyenangkan. Bandung: Rosdakarya, 2008.

[4] Suhardi, Pengembangan sumber belajar biologi. Yogyakarta: Universitas Negeri Yogyakarta, 2012.

[5] H. Siappa, A. Hikmat, and P. Katono, Agus, "Komposisi vegetasi, pola sebaran dan faktor habitat Ficus magnoliifolia (nunu pisang) di hutan pangale, desa toro, sulawesi tengah," Sci. Artic., vol. 19, no. 1, pp. 33-46, 2016.

[6] M. S. Nahdi and Darsikin., "Distribusi dan Kemelimpahan Spesies Tumbuhan Bawak pada Naungan pinus mercusii, Acacia auriculiformis dan Eucalyptus alba di Hutan Gama Giri Mandiri Yogyakarta.," J. Natur Indones., no. 33-44, 2014.

[7] A. Kusumadewi and R. P. Sancayaningsih, "Densitas dan Fekunditas Cembirit ( Tabernaemontana macrocarpa Jack .) di komunitas Acacia auriculiformis A . Cunn . ex Benth di Hutan Lindung Mangunan, Bantul Density and Fecundity of Cembirit ( Tabernaemontana macrocarpa Jack ) in Acacia auriculiformis," Procedding Biol. Educ. Conf., vol. 13, no. 1, pp. 420-426, 2016.

[8] N. T. R. I. Damayanti, "Potensi penegmbangan jambu kristalL ( Psidium guajava L ) berdasasrkan asspek agroklimat di jawa barat," Skripsi, 2016.

[9] Indriyanto, Ekologi hutan. Jakarta: Bumi Aksara, 2008.

[10] S. Syamsudduha and M. Rapi, "Penggunaan lingkungan sekolah sebagai sumber belajar dalam meningkatkan hasil belajar biologi," Lentera Pendidik., vol. 15, no. 1, pp. 18-31, 2012.

[11] A. F. Arsal, G. D. Dirawan, Y. Hala, and S. Tahmir, "Identifiksi Sumber Belajar pada Pembelajaran Berbasis Lingkungan di Jurusan Biologi Fakultas Matematika dan Ilmu Pengetahuan Alam Universitas Negeri Makassar Identification of Learning Resources on Environment Learning In Jurusan Biologi Fakultas Matemati,” J. Sainsmat, vol. VI, no. 2, pp. 73-83, 2017. 